\title{
TENDENCIES AND PROSPECTS OF THE RUSSIAN AGRICULTURE DEVELOPMENT
}

\author{
Chetvertakov I.M. ${ }^{1}$, Chetvertakova V.P. ${ }^{2}$ \\ ${ }^{1}$ Professor, Doctor of Economic Sciences (Advanced Doctor), Voronezh State Agrarian University \\ named after Emperor Peter the Great,
}

${ }^{2}$ Professor, Doctor of Economic Sciences (Advanced Doctor), Voronezh Institute of Economics and Social Management

\begin{abstract}
Agriculture plays a leading role in providing the country's food security and rural employment. In this regard, the study of the state and development of the agricultural economy is relevant. Much attention is paid in the economic literature to the problems of the Russian agriculture development. Nevertheless, in our opinion, the state of a number of industries of the agricultural sector is not accurately assessed, the mechanisms and prospects of development are not fully and deeply investigated. The purpose of scientific work is to analyze the state, identify mechanisms, tendencies and the most effective directions of agricultural development. As the object of research the enterprises of all categories of the Russian Federation engaged in the agricultural production are taken. To solve these problems a systematic approach, economic and statistical, economic and mathematical, forecasting and calculation and constructive research methods were used. In the course of the work the state of agriculture of the Russian Federation was determined, the prevailing tendencies in the production of various types of products were identified, the factors, driving forces and specific mechanisms of the functioning of the industries were identified. The causes and consequences for the agricultural sector of the country's economy of the systemic crisis of the 90-ies of XX century are revealed. The mechanisms and driving forces of economic recovery in certain sectors of agriculture in the early XXI century were identified. The directions, conditions were determined and forecasts of the main parameters of the industry development for the next 5-6 years were made. All this allowed assessing more accurately the reserves for further growth, the future state of agriculture, the change in the role and influence of Russia in the world food market.
\end{abstract} forecasts.

Keywords: agriculture, analysis, tendencies, current situation, development, economic growth,

\section{INTRODUCTION}

In the 90-ies of XX century the Russian agriculture suffered from severe economic crisis. In the twenty-first century the industry is undergoing restorative economic growth. However, it is not clear how long it will last, what will be the pace of economic growth, what place can Russia take in the world food market?

Agriculture is the most important sector of the Russian economy. The extensive nature of its conduct, the collapse of production during the liberal reforms years of the late twentieth century, the instability of production does not allow achieving food security of the country.

At the same time, the agriculture of the Russian Federation has a great production potential in the form of huge and not fully used land resources, large reserves of labor in rural areas, significant reserves for increasing production volumes due to increased plant and animal productivity, labor productivity growth.

The purpose of the research is to establish the state, identify tendencies and prospects of the Russian agriculture development. As the object of research the enterprises of all categories of farms of the agricultural sector are taken.

The opportunities of the industry were revealed in 2014-2016, when the volume of production in the country's economy as a whole decreased, and there was economic growth in agriculture. This allowed improving the food security of the country and became a leading exporter of grain in the world market. 
Quite a lot of scientific research is devoted to the Russian agriculture development, including in recent years $[1,2,4,6-9,14-20]$. At the same time, in our opinion, certain aspects of the state, reserves and mechanisms of development of the agricultural sector of the Russian economy are not fully and accurately disclosed, and development prospects are not determined. In this regard, the study aims to analyze the state, identify tendencies and prospects of the Russian agriculture development, the change of its role in the global food market.

Before the liberal reforms of the 90-ies of XX century the Russian agriculture played a significant role in the economy. Thus, this industry accounted for $11.5 \%$ of all fixed means of production in 1990 (in value terms), $12.9 \%$ of all workers employed in the country's economy, and $16.5 \%$ of the gross domestic product of the state was produced $[1,12]$.

\section{MATERIALS AND METHODS}

At considering the problems studied in the article, numerous data taken from several collections of the Federal State Statistics Service (Russtat) were used. Besides, the State program of the agriculture development and regulation of markets for agricultural products, raw materials and food for 2013-2020, the results of the authors' own research over the past 15 years were used. In the working on forecasts of the Russian agriculture development until 2021, the authors processed the statistical material on the acreage, yield and gross harvest of grain crops, sugar beet, sunflower, potatoes and vegetables in the Russian Federation from 1906 to 2015, livestock, productivity and production of the main sectors of livestock for all categories of farms. For the analysis of the agriculture state the economic and statistical method with the calculation of average, average weighted indicators, rates of development was widely used. The identification of trends in the development of agricultural industries and the justification of forecasts for the future was carried out by economic and mathematical methods of trend analysis based on various models with the designation of the determination coefficients. As possible models the authors tested exponential, linear, logarithmic, power, and polynomial of the second degree ones. The decision to choose the most appropriate model was made on the basis of the highest coefficient of approximation reliability $\left(R^{z}\right)$. As the most probable range of future values, the values for which different models gave close confidence coefficients were used. Taking into account that all sectors of agriculture are closely interrelated and dependent on each other and on many other factors, the article applies a systematic approach to their analysis, forecasting and definition of development prospects. In determining the future state of agriculture, changes in the place and role of Russian agricultural products in the world food markets, combined with a systematic approach, the calculation and constructive method of research was used.

\section{RESULTS}

The transition to free (market) prices and tariffs in 1992 caused immediately an acceleration of their growth rates. Prices for agricultural products sold in 1992 increased by 8.6 times, and for industrial products used in agricultural production, increased by 16.2 times. In the next two years prices for agricultural products of the first sphere continued to rise faster than in the second sphere, which brought the disparity of prices between them in 1994 in 3.7 times in favor of enterprises producing means of production for the village against the prices of agricultural products. From 1990 to 1996 the growth rates of crop production sales prices were by 1.4 times less than the growth rates of its cost price, and the prices of livestock products sales grew 2.5 times slower than its cost price. As a result, the level of profitability of crop production for those years decreased from $66.9 \%$ to $18.4 \%$, and in livestock it decreased from $15.5 \%$ to $48.3 \%$ payback.

In 1995 relative to 1990 the price disparity between agricultural and industrial products was 7.4, and in 2000 decreased to 6.6 times, but again in favor of industry. In construction the disparity of prices in 2000 was 2.6, for consumer goods -3.4 and for freight transportation - 5.9 times in favor of these industries.

Within agriculture in 1992 the price disparity between crop and livestock production was established in favor of the first in 3.37 times. From 1993 to 1999 (except for 1996), the growth rates of prices for livestock products were ahead the growth rates for crop production and in 1999 reached proportions typical for 1990. In 2000, the price proportions changed again in favor of crop production in 1.3 times compared to the production of livestock industry $[5,15,16]$.

In the twenty-first century, the disparity of prices between agriculture and other sectors of the economy continued to decline, but the agricultural economy was still not sufficiently supportive. This

Submit Date: 09.01.2018, Acceptance Date: 23.02.2018, DOI NO: 10.7456/1080MSE/148

Research Article - This article was checked by Turnitin

Copyright (C) The Turkish Online Journal of Design, Art and Communication 
led to a very large loss of agricultural production and a decrease in the share and importance of the agricultural sector in the country's economy. Thus, in 2014, agriculture accounted for only $2.7 \%$ of fixed assets instead of $11.5 \%$ and produced only $3.3 \%$ of the country's GDP instead of $16.5 \%$ in 1990 [12].

The social position of agricultural workers has also significantly deteriorated. If in 1990 the level of wages in agriculture in relation to the average level in the economy was $95 \%$, in $1998-44.5 \%$, and in $2014-54.5 \%$, which led to the transition of the most qualified personnel in other industries, a significant increase in the proportion of rural residents living below the poverty line.

The deepening of the price disparity, which had a negative impact on agriculture, was due not only to the low competitiveness of the industry in relation to the monopolized sectors of the I and III spheres of agriculture, but also a decrease in real disposable income of the population of the Russian Federation from 1990 to 1999 by $61.5 \%$, which reduced purchasing power, including food and demand for agricultural products. After the default in 1998, real incomes of the population began to grow and there were positive trends in the development of agriculture, but even in 2014 the gross product of the industry was $7.5 \%$ lower than in 1990 .

For the designation of the development prospects the identification of trends and specific mechanisms determining the functioning of agriculture of the Russian Federation is of great importance. The decline in production in the first half of the 90-ies of XX century was due to the reduction in acreage, livestock, and reducing crop yields in crop production and animal productivity in cattle, pig, and sheep breeding.

Thus, only from 1990 to 2000, the acreage in Russia decreased from 117.7 million hectares to 85.4 million hectares. Although more slowly, but this process took place in the XXI century. The acreage of agricultural crops in 2014 amounted to 78.5 million hectares, i.e. by $33.3 \%$ less than in 1990. This trend was caused both by a decrease in the efficiency of crop production since the beginning of the 90-ies of XX century, and the inability to process the entire area due to the lack of agricultural machinery. At the same time, the acreage of individual crops with high profitability has increased significantly (Table 1). Thus, in 2016, the area occupied by sunflower increased in 2.8 times, by vegetables $-12 \%$ compared to 1990 , while the area for potato, grain and sugar beet amounted to $65.7 \%$, $74.7 \%, 65.7 \%$, respectively, to the level of 1990 .

\section{Table 1. Acreage of agricultural crops in farms of all categories in the Russian Federa- tion, thsd hectares}

\begin{tabular}{|l|c|c|c|c|c|c|c|c|c|}
\hline \multicolumn{1}{|c|}{ Crops } & 1990 & 1995 & 2000 & 2005 & 2010 & 2015 & $\begin{array}{c}2015 \\
\text { in \% to } \\
1990\end{array}$ & 2016 & $\begin{array}{c}2016 \\
\text { in \% to } \\
1990\end{array}$ \\
\hline Grain - total & 63068 & 54705 & 45585 & 43593 & 43194 & 46642 & 74,0 & 47110 & 74,7 \\
\hline Sunflower & 2739 & 4127 & 4643 & 5568 & 7153 & 7005 & 255,8 & 7598 & 277,4 \\
\hline Sugar beet & 1460 & 1085 & 805 & 799 & 1160 & 1022 & 70,0 & 1108 & 75,9 \\
\hline Potatoes & 3124 & 3409 & 2834 & 2277 & 2212 & 2128 & 68,1 & 2053 & 65,7 \\
\hline Vegetables & 618 & 758 & 744 & 641 & 662 & 694 & 112,3 & 692 & 112,0 \\
\hline
\end{tabular}

Elimination of control over pricing in the Russian Federation led to the deterioration of not only production, but also financial indicators of agriculture. So, if in 1990 in the regions of the Central black earth region (CBR) $6.7 \%$ of agricultural enterprises were unprofitable, and in Russia as a whole $2.7 \%$, in 1998 - respectively $88.8 \%$ and $87,5 \%[5,15,16]$.

The level of profitability of all economic activities of agricultural enterprises of the Russian Federation as a whole in 1994, 1996, 1997, and 1998 was negative. And if you recalculate the revenue received from the sale of agricultural products in the prices of the period of implementation of production costs (for 4-8 months earlier), taking into account the time lag of the production process and high inflation rates, production in agricultural enterprises was actually unprofitable in 1992, 1993, 1995, 
1999 and 2000. Practically from 1991 to 2001 most of the agricultural enterprises were unable to conduct even simple reproduction at the expense of their own economic activities.

Agricultural enterprises got rid of the number of animals at a fairly high rate, as the majority of livestock products in the mid-1990s had a payback rate less than $50 \%$. The number of cows in the agricultural enterprises of the CBR in 1996 - 2000 became 2.0 times less than in 1986 - 1990, young cattle -3.0 times, pigs -4.2 times, sheep and goats -15.6 times less.

At the beginning of the twenty-first century, the decline in the number of cattle has not stopped, but the rate of decline has decreased significantly. As a result, in 2016, the number of cattle in farms of all categories of the Russian Federation was 1/3 (33.3 \%) of the livestock in 1990, and cows $-40.5 \%$. The number of sheep has been regenerating since 2000, but at a slower rate than it was in the 1990s. As a result, in 2016, the number of sheep was $42.6 \%$ of the number that was 26 years ago. The number of pigs due to the construction of large pig-breeding complexes was restored at a higher rate. However, in 2016, it was $57.4 \%$ compared to 1990 level [7, 8] (Table 2).

Table 2. Number of animals and birds at the end of the year in farms of all categories of Russia, million heads

\begin{tabular}{|l|c|c|c|c|c|c|c|c|c|}
\hline Animal species & 1990 & 1995 & 2000 & 2005 & 2010 & 2015 & $\begin{array}{c}2015 \text { in } \\
\% \text { to } \\
1990\end{array}$ & 2016 & $\begin{array}{c}2016 \\
\text { in \% } \\
\text { to } \\
1990\end{array}$ \\
\hline Cattle & 57,0 & 39,7 & 27,5 & 21,6 & 20,0 & 19,0 & 33,3 & 18,8 & 33,0 \\
\hline including cows & 20,5 & 17,4 & 12,7 & 9,5 & 8,8 & 8,4 & 41,0 & 8,3 & 40,5 \\
\hline Pigs & 38,3 & 22,6 & 15,8 & 13,8 & 17,2 & 21,5 & 56,1 & 22,0 & 57,4 \\
\hline $\begin{array}{l}\text { Sheep and } \\
\text { goats }\end{array}$ & 58,2 & 28,0 & 15,0 & 18,6 & 21,8 & 24,9 & 42,8 & 24,8 & 42,6 \\
\hline $\begin{array}{l}\text { Chickens and } \\
\text { cocks }\end{array}$ & 159 & 109 & 93 & 97 & 110 & 124 & 78,0 & 128 & 80,5 \\
\hline
\end{tabular}

The productivity of agricultural crops from 1990 to 2000 against the background of reduction of doses of organic and mineral fertilizers, deterioration of production material and technical base decreased. Since 2000, the predominant trend has been the increase in the major crops yield, which by 2016 allowed exceeding significantly the level of 1990. Thus, the yield of grain from $13.1 \mathrm{C} / \mathrm{ha}$ in 1998 rose in the Russian Federation to $26.2 \mathrm{C}$ / ha in 2016, which is $34.4 \%$ more than in 1990 , the yield of sugar beet from $152 \mathrm{C} /$ ha in 1998 increased to $470,0 \mathrm{C} /$ ha in 2016 , which is almost 2 times more than in 1990 (Table 3).

Table 3. The average yield of crops in Russia, C/ha

\begin{tabular}{|l|c|c|c|c|c|c|c|c|c|}
\hline \multicolumn{1}{|c|}{ Crops } & 1990 & 1995 & 2000 & 2005 & 2010 & 2015 & $\begin{array}{c}2015 \text { in } \\
\% \text { to } \\
1990\end{array}$ & 2016 & $\begin{array}{c}2016 \text { in } \\
\% \text { to } \\
1990\end{array}$ \\
\hline $\begin{array}{l}\text { Grain - total (in } \\
\text { weight after } \\
\text { completion) }\end{array}$ & 19,5 & 13,1 & 15,6 & 18,5 & 18,3 & 23,7 & 121,5 & 26,2 & 134,4 \\
\hline Sunflower & 13,7 & 10,6 & 9,0 & 11,9 & 9,6 & 14,2 & 103,6 & 15,1 & 110,2 \\
\hline Sugar beet & 240,0 & 188,0 & 188,0 & 282,0 & 241,0 & 388,0 & 161,7 & 470,0 & 195,8 \\
\hline Potatoes & 104,0 & 118,0 & 105,0 & 124,0 & 100,0 & 159,0 & 152,9 & 153,0 & 147,1 \\
\hline Vegetables & 167,0 & 148,0 & 143,0 & 170,0 & 180,0 & 225,0 & 134,7 & 227,0 & 135,9 \\
\hline
\end{tabular}

Submit Date: 09.01.2018, Acceptance Date: 23.02.2018, DOI NO: 10.7456/1080MSE/148

Research Article - This article was checked by Turnitin Copyright (C) The Turkish Online Journal of Design, Art and Communication 
Accordingly, the coincidence of negative trends in the reduction of acreage and yields in the 90ies of XX century led to a sharp drop in the production of the vast majority of crops. Thus, the volume of grain production in farms of all categories decreased from 116.7 million tons in 1990 to 65.4 million tons in 2000, sugar beet - from 32.3 million tons to 21.2 million tons $[10,11]$.

Also, the increase in yield since the beginning of the XXI century and a small partial increase in acreage after 2010 contributed to a fairly rapid increase in crop production. Thus, in 2016, 120.7 million tons of grain was produced, sugar beet -51.4 million tons, sunflower -11.0 million tons, which amounted to the volume of production in 1990 for grain $103.4 \%$, sugar beet $-159.1 \%$, sunflower seeds $-323.5 \%$ (Table 4$)$.

Table 4. Production volumes of the main types of agricultural products in Russia, mln tons

\begin{tabular}{|l|c|c|c|c|c|c|c|c|c|}
\hline \multicolumn{1}{|c|}{$\begin{array}{c}\text { Types of } \\
\text { production }\end{array}$} & 1990 & 1995 & 2000 & 2005 & 2010 & 2015 & $\begin{array}{c}2015 \\
\text { in \% } \\
\text { to } \\
1990\end{array}$ & 2016 & $\begin{array}{c}2016 \\
\text { in \% } \\
\text { to } \\
1990\end{array}$ \\
\hline $\begin{array}{l}\text { Grain - total (in } \\
\text { weight after } \\
\text { completion) }\end{array}$ & 116,7 & 63,4 & 65,4 & 77,8 & 61,0 & 104,8 & 89,8 & 120,7 & 103,4 \\
\hline Sunflower & 3,4 & 4,2 & 3,9 & 6,5 & 5,3 & 9,3 & 273,5 & 11,0 & 323,5 \\
\hline Sugar beet & 32,3 & 19,1 & 14,1 & 21,3 & 22,3 & 39,0 & 120,7 & 51,4 & 159,1 \\
\hline Potatoes & 30,8 & 39,9 & 29,5 & 28,1 & 21,1 & 33,6 & 109,1 & 31,1 & 101,0 \\
\hline Vegetables & 10,3 & 11,3 & 10,8 & 11,3 & 12,1 & 16,1 & 156,3 & 16,3 & 158,2 \\
\hline Milk & 55,7 & 39,2 & 32,3 & 31,1 & 31,8 & 30,8 & 55,3 & 30,8 & 55,3 \\
\hline $\begin{array}{l}\text { Meat- total (in } \\
\text { slaughter weight) }\end{array}$ & 10,1 & 5,8 & 4,4 & 4,9 & 7,2 & 9,5 & 94,1 & 9,9 & 98,0 \\
\hline Cattle & 4,4 & 2,7 & 1,9 & 1,8 & 1,7 & 1,6 & 36,4 & 1,6 & 36,4 \\
\hline Pigs & 3,5 & 1,9 & 1,6 & 1,5 & 2,3 & 3,1 & 88,6 & 3,4 & 97,1 \\
\hline Poultry & 1,8 & 0,9 & 0,8 & 1,4 & 2,8 & 4,5 & 250,0 & 4,6 & 255,6 \\
\hline Sheep and goats & 0,4 & 0,3 & 0,1 & 0,2 & 0,2 & 0,2 & 50,0 & 0,2 & 50,0 \\
\hline Eggs, billion pieces & 47,5 & 33,8 & 34,0 & 37,1 & 40,6 & 42,5 & 89,5 & 43,6 & 91,8 \\
\hline Wool, thsd tons & 204,0 & 93,0 & 40,0 & 48,0 & 54,0 & 56,4 & 27,6 & 56,0 & 27,4 \\
\hline Honey, thsd tons & 46,1 & 57,7 & 53,9 & 52,0 & 52,0 & 68,0 & 147,5 & 70,0 & 151,8 \\
\hline
\end{tabular}

The recovery of livestock is much slower. This is due to the large drop in the volume of production in this industry in the 90-ies of XX century. Thus, the volume of production of livestock and poultry for slaughter (in slaughter weight) by 2000 decreased to $44.0 \%$ to the level of 1990 , and by 2016 there was a recovery to $98 \%$. Milk in 2000 in all categories of farms of the Russian Federation was produced only $57.9 \%$ to the level of 1990, and in $2016-55,3 \%$. Even a significant increase in dairy productivity of cows in all categories of farms from $2.731 \mathrm{~kg}$ per 1 cow per year in 1990 to $4.218 \mathrm{~kg}$ in 2016 did not allow compensating the reduction in the number of dairy herds by 2.5 times [7] (Table 5).

Table 5. Productivity of cattle and poultry in farms of all categories of the Russian Federation 
The Turkish Online Journal of Design, Art and Communication - TOJDAC

ISSN: 2146-5193, March 2018 Special Edition, p. 410-418

\begin{tabular}{|l|l|l|l|l|l|l|l|l|l|}
\hline \multicolumn{1}{|c|}{ Indicators } & 1990 & 1995 & 2000 & 2005 & 2010 & 2015 & $\begin{array}{c}2015 \text { in } \\
\% \\
1990\end{array}$ & 2016 & $\begin{array}{c}2016 \\
\text { in \% to } \\
1990\end{array}$ \\
\hline $\begin{array}{l}\text { Milk yield per 1 } \\
\text { cow, kg }\end{array}$ & 2731 & 2153 & 2502 & 3176 & 3776 & 4134 & 151,4 & 4218 & 154,4 \\
\hline $\begin{array}{l}\text { The products of } \\
\text { the cultivation of } \\
\text { 1 head (growth } \\
\text { and offspring), } \\
\text { kg: }\end{array}$ & 121 & 93 & 114 & 127 & 144 & 152 & 125,6 & 150 & 124,0 \\
\hline \multicolumn{1}{|c|}{ Cattle } & 118 & 99 & 114 & 154 & 179 & 209 & 177,1 & 203 & 172,0 \\
\hline $\begin{array}{l}\text { Phe average } \\
\text { annual wool clip } \\
\text { in the physical } \\
\text { weight of 1 } \\
\text { sheep, kg }\end{array}$ & 3,9 & 2,9 & 3,1 & 3,0 & 2,6 & 2,4 & 61,5 & 2,4 & 61,5 \\
\hline $\begin{array}{l}\text { The average } \\
\text { annual egg } \\
\text { production of } \\
\text { laying hens in } \\
\text { agricultural } \\
\text { organizations, } \\
\text { pieces }\end{array}$ & 236 & 212 & 264 & 301 & 307 & 310 & 131,4 & 308 & 130,5 \\
\hline
\end{tabular}

The volume of production in farms of all categories of the Russian Federation in comparable prices from 1990 to 1996, inclusive, decreased by an average by $6.1 \%$ per year, including in agricultural enterprises - by $9.4 \%$, which led to a decrease in the volume of production in them in 1998 in 2.8 times compared to 1990 .

In the twenty-first century the trend of economic growth was dominated, but it was the recovery of economic growth. Due to differences in weather conditions over the years, it had very significant fluctuations in the chain index of agricultural production in all categories of farms from $88.7 \%$ in barren 2010 to $123.0 \%$ - in 2011 . This index was more typical in $2013-105.8 \%$, in $2014-103.5 \%$, in $2015-103.0 \%[10,11]$.

Economic growth, which prevailed in the Russian agriculture in the XXI century, allowed surpassing in 2016 the pre-reform level of production in 1990 by $59.1 \%$ for sugar beet, $223.5 \%$ - for sunflower seeds. In 2015, grain was produced by $10.2 \%$ less, but in 2016 - by $3.4 \%$ more than in 1990.

As the rate of economic growth in animal husbandry was lower than in crop production, the volume of meat production of all animal species in slaughter weight in 2016 was 9.9 million tons or $98.0 \%$ by 1990 , eggs $-91.8 \%$. A sharp decline in milk production in the 90 -ies of XX century associated with a decrease in both livestock and productivity of cows was replaced by a recession in the XXI century. Rather high growth rates of dairy productivity of cows compensate the continuing decline in livestock, and the volume of milk production remains at a low leve $1-55.3 \%$ in 2016 to the level of 1990.

Elimination of control over pricing in the Russian Federation led to the deterioration of not only production, but also financial indicators of agriculture. If in 1990 in Russia $2.7 \%$ of the enterprises were unprofitable as a whole, in $1998-87.5 \%$. After the default of 1998, the share of lossmaking farms in agricultural production tended to decrease. Thus, if in 2003 it was still more than $50 \%(53.3$ $\%$ ), in $2005-42.3 \%$, in $2012-29.0 \%$ and only $18.7 \%$ - in 2015 . 
In the XXI century there was a tendency to increase the level of profitability of both agricultural products and industry assets. Thus, in 2003 they were $2.6 \%$ and $0.8 \%$, in $2005-6.7 \%$ and $2.8 \%$, in $2014-17.4 \%$ and $4.9 \%$, respectively, and in 2015 the level of profitability of agricultural production was $21.3 \%$, and the level of return on assets was $7.4 \%$. But it should be noted that the high rates for the last two years have been inflated due to Russia's response to the sanctions of the EU, the United States and some other states, expressed the ban on the supply of a number of agricultural products from these countries, which caused an increase in prices for them in the national market. In addition, the fall in the ruble exchange rate in these years has increased profitability from exports of agricultural products from Russia.

\section{CONSIDERATION}

There are quite a lot of opinions about the directions of strategic development of the agro-industrial complex of Russia and they differ significantly $[2,3,4,6,13,14,17,18,19,20]$. Assessing the prospects for the development of agriculture in Russia and its impact on the world food market in the nearest years, it can be said that the export of meat, vegetables, fruits and dairy products from the country will be insignificant and many times less than the import of these products from other countries to Russia in order to meet the needs of the population. Russia has already become one of the leading exporters of grain and the volume of its supplies, as well as sunflower oil may further increase. The development of agriculture in the Russian Federation will be constrained by the low level of state support relative to other countries, insufficient amount of agricultural machinery, fertilizers, low wages (almost 2 times lower than in the country's economy as a whole), small disposable income of the country's population as a whole.

The authors made an attempt to predict the production indicators of the crop industry for the next 5-6 years. For this purpose, the statistical material was collected about the yield, acreage and gross harvest of the main crops: grain, sugar beet, sunflower, potatoes, and vegetables in the Russian Federation from 1906 to 2015 inclusive.

Based on the trend analysis, the calculation of future (up to 2021) yields, acreage, gross production was carried out. As maintaining the current dynamics the grain yield in Russia in 2021 may be $25.3 \mathrm{C} /$ ha, sugar beet $-506.6 \mathrm{C} / \mathrm{ha}$, sunflower $-15.8 \mathrm{C} /$ ha. The gross harvest of grain crops from 2015 to 2021 can increase from 104.8 to 130.6 million tons, sugar beet - from 39.0 to 53.3 million tons, sunflower - from 9.3 to 11.8 million tons, potatoes - from 33.6 to 34.1 million tons, vegetables from 16.1 to 17.5 million tons with the determination coefficient (R2) for sugar beet, sunflower and vegetables more than 0.7 . At the same time, Russia will remain the largest importer of fruits and vegetables, although the government's programs allow increasing their production at a higher rate than before.

At the end of the twentieth century, the livestock industry in Russia on the intensity of production and productivity of animals conceded significantly to advanced Western countries. Nevertheless, due to the large size of the livestock, the production of animal products was provided at the level of medical consumption norms. Although in the XXI century the productivity of all species of animals in the country has increased significantly, but the smaller size of the livestock remains. Thus, in 2016, cattle were 3 times less than in 1990, pigs - 1.7 times, sheep - 2.3 times less. Therefore, in 2016 the country produced $55.3 \%$ milk, $91.8 \%$ - eggs, meat - $98.0 \%$ to the level of 1990 .

At the end of 2016, Russia had 146.8 million citizens. By the end of 2021, the population of the country may increase to about 148 million people. The established rates of development allow predicting the output of almost complete self-sufficiency of the country in 2021 on the main types of crop production, and on livestock products only for meat and eggs, the production of which can grow to 11.8 million tons and 44.4 billion pieces, respectively.

Milk production has been declining recently. The measures taken by the state to support this industry and increase the profitability of milk production change the trend to a positive one. But to meet the needs of the population of the Russian Federation in 2021 it will need to produce 57.7 million tons, and in 2016 it was produced 30.8 million tons, self-sufficiency for this product will not be achieved. The task is complicated not only by weak incentives for the development of dairy cattle breeding, but also by its great inertia due to the long cycle of reproduction. Under the most favorable circumstances, the volume of milk production in all categories of farms can be increased to 38-41 million tons by 2022 , which will be $68.4 \%$ of the need, and Russia will remain among the largest importers of milk powder, cream, cheese and animal oil. 
Certainly the changes in the global market situation in one direction or another, the expansion of economic wars may slightly slow down or accelerate these processes. In general, these forecasts can be used in the development of Federal and regional programs for the agricultural sectors development. The search for breakthrough measures in the development of almost all sectors of agriculture in Russia, the possibilities of accelerated growth of labor productivity require further research.

\section{CONCLUSIONS}

In the first half of the 90-s of the XX century, the decline in agricultural production in Russia was due to both the reduction of acreage, livestock, and the reduction of crop yields in crop production and animal productivity in cattle, pig, sheep, poultry. The acreage of agricultural crops in 2014 amounted to 78.5 million hectares, i.e. $33.3 \%$ less than in 1990.

In 2016, the number of cattle in farms of all categories of the Russian Federation was unacceptably low $-33.3 \%$ of the livestock in 1990 , and cows $-40.5 \%$. Since 2000 there was the restoration of the sheep population, but more slowly than it was decreased in the 90-ies of the twentieth century. As a result, in 2016 the number of sheep was $42.6 \%$ of the number that was 26 years ago. The recovery of the pig population due to the construction of large pig breeding complexes was carried out at a higher rate. However, in 2016, it was $57.4 \%$ of the 1990 level.

Grain yield from 13.1 C/ha in 1998 rose in Russia to $26.2 \mathrm{C} /$ ha in 2016 , that is $34.4 \%$ more than in 1990. Sugar beet yield rose from $152 \mathrm{C} /$ ha in 1998 to $470.0 \mathrm{C} /$ ha in 2016 , which is almost 2 times more than in 1990. In 2016120.7 million tons of grain was produced, sugar beet -51.4 million tons, sunflower -11.0 million tons, which amounted to the volume of production of grains $103,4 \%$, sugar beet $-159,1 \%$, sunflower seeds $-323,5 \%$ in 1990 .

The volume of production of livestock and poultry for slaughter (in slaughter weight) in 2000 decreased to $44.0 \%$ of the 1990 level, but by 2016 it was restored to $98 \%$. In 2000, milk in all categories of farms of the Russian Federation was produced only 57,9 \% to the level of 1990, and in 2016 $-55,3 \%$. Even a significant increase in dairy productivity of cows in all categories of farms from $2,731 \mathrm{~kg}$ per $1 \mathrm{cow}$ per year in 1990 to $4,218 \mathrm{~kg}$ in 2016 did not allow compensating for the reduction in the number of dairy herds by 2.5 times.

The volume of production in farms of all categories of the Russian Federation in comparable prices from 1990 to 1996, inclusive, decreased by an average of $6.1 \%$ per year, including in agricultural enterprises - by $9.4 \%$, which led to a decrease in production in them in 1998 by 2.8 times compared to 1990. Economic growth, prevailing in agriculture in Russia in the XXI century, in 2016 allowed surpassing the pre-reform level of production in 1990 by $59.1 \%$ for sugar beet, $223.5 \%$ - for sunflower seeds, $3.4 \%$ - for grain. The volume of meat production of all animal species in slaughter weight in 2016 was 9.9 million tons or $98.0 \%$ by 1990 , eggs $-91.8 \%$, and milk production amounted to only $55.3 \%$ in 2016 to the level of 1990 .

According to our forecasts, the gross harvest of grain crops from 2015 to 2021 can be increased to from 104.8 to 130.6 million tons, sugar beet - from 39.0 to 53.3 million tons, sunflower - from 9.3 to 11.8 million tons, potatoes - from 33.6 to 34.1 million tons, vegetables - from 16.1 to 17.5 million tonnes. Steady pace of development allow predicting the output of almost complete self-sufficiency of the country in 2021 for the main types of crop products and animal products only on meat and eggs, the production of which could rise to 11.8 million tons and 44.4 billion pieces, respectively. The volume of milk production in all categories of farms can be increased to 38-41 million tons by 2022 , which will be $68.4 \%$ of the demand.

Our research showed that due to the development of agriculture Russia can increase the export of grain, vegetable oil in the next 5-6 years and take on these products a leading position in the world food market. There are prerequisites for the expansion of exports of sugar beet processing products. Over the years, the import of pork, poultry will reduce significantly, which will shrink to an insignificant size. Imports of dairy products, vegetables and fruits may decrease by $30-34 \%$, but still it will be quite large.

\section{REFERENCES}

Bautin V.M. Statistical Analysis of the Dynamics of the Development of Agriculture in Russia in the Post-Soviet period / V.M. Bautin, Yu.N. Romantseva // Economics of Agriculture in Russia. - 2016. №6. - P. 26-32.

Submit Date: 09.01.2018, Acceptance Date: 23.02.2018, DOI NO: 10.7456/1080MSE/148

Research Article - This article was checked by Turnitin

Copyright (C) The Turkish Online Journal of Design, Art and Communication 
Bogoviz A. Import Substitution as a Target Point of State Regulation of the AgroindustrialComplex / A. Bogoviz, Yu. Bugai, A. Minenko // APK: economy, management. - 2016. - № 12. - P. 67-73.

The government program for the development of agriculture and market regulation for agricultural products, raw materials and food for the period of 2013-2020. http://government.ru/programs/208/

Dolgushkin N.K. On the Need to Determine Strategic Priorities in the Development of the Agro-Industrial Complex / N.K. Dolgushkin // Economics of Agriculture in Russia. - 2016. - № 6. - P. 11-18.

Intensive Economic Growth and Innovative Development of Agriculture: a monograph / Under the general editorship of prof. I.M. Chetvertakov, prof. V.P. Chetvertakova. - Voronezh: Publishing house "ISTOKI", 2010. - 240 p.

Miloserdov V.V. Food Security and Import Substitution // Economics, Work, Management in Agriculture. - 2015. - № 2 (23).

Panfilov V.A. Food security of Russia and the sixth technological tenor in the AIC /V.A. Panfilov // Vestnik of the russian agricultural science. - 2016. - № 1. - P. 10-12.

Pulatov Z.F. Import substitution - key factor of specializing the regional agriculture /Z.F. Pulatov // Vestnik of the russian agricultural science. - 2016. - № 4. - P. 9-11.

Royter L.M. The changes trends in the economic soundness of the poultry farming enterprises / L.M. Royter, V.I. Fisinin, A.G. Akopyan //Vestnik of the russian agricultural science. - 2017. - № 1. - P. $27-$ 32.

Russian Statistical Yearbook. 2016: collection of articles. / Rosstat. - M., 2016. - 725 p.

Russia in figures. 2016: collection of articles. / Rosstat - M., 2016. - 543 p.

Agriculture, Hunting and Hunting Sector, Forestry in Russia: collection of articles. 2016: Rosstat [Electronic resource]. - http://www.gks.ru (date of the application: 15.03.2018).

Ushachev I. Scientific Problems of Import Substitution and Formation of the Export Potential of the Products of the Agro-Industrial Complex in Russia // AIC: Economy, Management. - 2016. - № 1.- P. 4-22.

14. Ushachev I. Strategic Directions of Sustainable Development of Russia's Agro-Industrial Complex. Ushachev // AIC: Economy, Management. - 2016. - № 11. - P. 4-15.

Chetvertakova V.P. Price as a factor of economic growth and development of the agroindustrial complex: diss. ... doc. econ. Sciences (08.00.01) / V.P. Chetvertakova. - Voronezh, 2003. -361 p.

Chetvertakova V.P. Prices and Pricing in the Functioning and Development of the AgroindustrialComplex: Monograph / V.P. Chetvertakova; VoronezhState Academy of Forestry and Technologies. Voronezh. The Publishing House of Voronezh State University, 2003. - 240 p.

Gov (2015), The distribution of subsidies in 2015 to support agriculture, The Russian Government, 2015. [Online]. Available: http://government.ru/docs/16916 (date of the application: 12.03.2018).

Chetvertakov S. Corn and soy in Russia: the latest fad or a new cash cow? / Proceedings of the 24th International Scientific Conference Agrarian Perspectives XXIV (2015). - Global Agribusiness and Rural Economy: 199-207. DOI: 10.13140/RG.2.1.1054.7929 (date of the application: 25.01.2018).

Chetvertakov S. Crop choice decision under uncertainty: a case study in Russia /S. Chetvertakov // Russian Journal of Agricultural and Socio-Economic Sciences, Issue 7 (55), July 2016, pp. 25-34. ISSN 2226-1184/ DOI: http://dx.doi.org/10.18551/rjoas.2016-07.04 (date of the application: 14.03.2018).

Chetvertakov S., Zimmer Y. Corn and Soybeans in the Central Black Soil Region of Russia: A fundamental shift in cropping patterns ahead of us? / International Journal of Agricultural Management, Volume 5, Number 3, 1 July 2016, pp. 44-52(9). DOI: https://doi.org/10.5836/ijam/2016-05-44 (date of the application: 05.02.2018). 